\title{
A CLUSTER APPROACH TO THE FORMATION OF TOURISM DESTINATIONS IN WESTERN UKRAINIAN CROSS-BORDER REGIONS
}

\author{
Vasyl Kyfyaka, Olexander Kyfyak \\ ${ }^{a}$ Chernivtsi Institute of Trade and Economics, of Kyiv National University of Trade and Economics, Department of Management, \\ International Economics and Tourism; e-mail: tourbuc@ukr.net \\ ${ }^{b}$ Yuriy Fedkovych Chernivtsi National University, Faculty of Economics, Department of Marketing, Innovations and Regional \\ Development; e-mail: o.kyfyak@chnu.edu.ua
}

\begin{abstract}
The research aims at exploring western Ukrainian cross-border regions where many natural recreational resources, historical, cultural and architectural monuments, a developed transport infrastructure, strong ethnic ties and wide opportunities for tourism flows from the cross-border regions of neighboring countries are found. To achieve this goal, the authors studied foreign experience, in particular the processes of the creation and operation of clusters in Romania and Poland which helped to identify certain stages of development of tourism destinations based on a cluster approach. Comparison of the activities of already established tourism clusters in Ukraine and abroad has helped to establish a list of major business structures that might become a part of a cluster and be involved in the formation of a tourism destination. Based on an analysis of natural and recreational potential, and cultural and historical heritage in western Ukrainian cross-border regions, possible profiles of tourism destinations, and the interest of tourist and other enterprises to be brought together into tourism clusters, are determined, and this has been confirmed by a survey
\end{abstract}

\section{KEYWORDS}

cluster, approach, cross-border regions, tourism destinations, formation of destinations

\section{ARTICLE INFORMATION DETAILS}

Received:

26 November 2020

Accepted:

11 May 2021

Published:

18 June 2021

\section{INTRODUCTION}

Western Ukrainian cross-border regions in which the tourism organizations that produce typical services, and the businesses that offer related services, can successfully operate, use different approaches to the development of small and medium-sized businesses, create new jobs, increase revenues for local budgets, ensure investment attractiveness, etc. It is strategically important for companies operating in these areas, where creating a tourism destination is possible, to provide tourism products with basic and related services at a particular destination for an additional fee. Awareness and understanding of the need for cooperation with other enterprises in the future destination, action on maintaining contacts with related organizations involved in the formation of a tourism product, is the key to the sustainable on-going operation of individual businesses.

At the same time, the formation of tourism destinations in western Ukrainian cross-border regions has its own characteristics and requires the definition of clear goals, priority areas for the tourism development profiles of future destinations, development of methodology of which one aspect can be a cluster approach. All this determines the relevance of this academic research.

The purpose of this article is to study the possibilities offered by using a cluster approach in the formation 
of tourism destinations in western Ukrainian crossborder regions based on studying foreign experience and determining the individual stages of an approach for making tourism destinations, including tourism potential analysis and cluster model development taking into account a cross-border location.

\section{LITERATURE REVIEW}

Many foreign and Ukrainian academics consider effective internal management of available resources to be decisive in the development of an area. Issues of regional development, investment attraction, resource provision, the formation of competitive advantages, economic zoning and state regional economic policy in new economic conditions are covered in the works of Algieri, Aquino, Succurro (2018); Beltramo, Rostagno, Bonadonna (2018); Bobrovska, Krushelnytska, Latinin, Lypovska, Dreshpak (2017); Melnik (2018); Mazaraki (2019); Oteshova et al. (2020); Stasiak (2007); Varnalius (2005), etc.

Thus Varnalius, in particular, believes that the resource potential of a region is "the main basis for the formation of a mechanism for the realization of its economic interests" (Varnalius, 2005, p. 78). While analyzing the resources of an area Melnik distinguishes "labor, natural resources (water, land, mineral, biological, forest), products, infrastructure, finance" (Melnik, 2018, p. 9). Gerasymenko and a group of academics confirm this, paying attention to the natural resource potential of an area which means "all available types of resources - mineral, land, water, biological, recreational, biosphere, etc." (Gerasymenko, 2016, p. 68). The works of these authors consider the theoretical and methodological issues of resource usage in the area of their development and management, the planning of economic activities, the implementation of innovations, etc.

Porter, an American academic, has made a significant contribution to the use of the cluster approach to the development of regions. He defines clusters as "geographically concentrated groups of interdependent companies, specialized suppliers, service providers, firms in related industries, as well as organizations related to their activities (e.g. universities, standardization agencies, trade associations) in certain areas that compete, but at the same time conduct common activities" (Porter, 2005, pp. 205-206). He describes in detail the structural factors determining the intensity of competition, as well as the development of the industry and competitive strategy at different stages of its evolution (Porter, 2016). Analyzing the organization of productive forces and their relationship with the concept of competitiveness, Porter found that the most competitive multinational companies are not located haphazardly, but tend to concentrate in one country or region due to the desire to generate synergies through interaction with other firms.

A cluster is formed exactly on such a basis: a set of firms and industries, interacting with each other and contributing to the growth of each other's competitiveness. As Yalçınkaya and Güzel point out, "relationships and connections of a tourism cluster are expected to be more active and complicated, utilizing network and its advantages are unavoidable for tourism companies" (Yalçınkaya, Güzel, 2019, p. 33).

Clustered enterprises are the most efficient. Thus, Naumanen emphasizes that clusters are a geographical concentration or group of closely located and interconnected enterprises in an industry (Naumanen, 2019). Experience across the world shows that "there are almost three times as many global frontier firms in specialised clusters than in other locations" (Naumanen, 2019, p. 5).

Investigating the contribution of tourism to the economic sustainability of a region and its integration into a regional development strategy, a group of non-Ukrainian academics, Bellini, Grillo, Lazzeri and Pasquinelli, conducted an analysis focusing on the development of "smart specialization strategy". They identified the potential relevance of tourism as a factor for regional economic stability.

Regarding the use of a cluster approach in tourism, the research of Novelli, Schmitz and Spencer is important. In their research "Networks, clusters and innovations in tourism: the Great Britain experience" they emphasize that clusters develop innovative opportunities for small and middle-sized businesses and ensure their competitiveness in a tourism environment. They emphasize clusters should not be seen as a simple and spontaneous process due to the nature of the participating enterprises, but as a very complex process involving intensive stakeholder cooperation (Novelli, Schmitz, Spencer, 2006).

The academic and analytical report "The development of cross-border cooperation" released by the M. Dolishniy Institute of Regional Research of the National Academy of Sciences of Ukraine (Kravtsiv, 2015), as well as the academic researches of Benner (2017) are devoted to a regional and innovative development of tourism based on a cluster approach. Research in this area was also conducted by Korzh and Basyuk (2017), Mikula, Matvyeyev and Tymechko (2014) and Odinokova (2019) and others.

At the same time, the use of foreign experience in the formation of tourism destinations based on a cluster approach in cross-border regions, research into their tourism potential, cluster model development and approaches to tourism destination formation, remain unresolved and require further research. 


\section{RESEARCH METHODOLOGY}

The following scientific methods and approaches were used in the article:

- analysis and synthesis of tourism clusters in Poland and Romania, the determination of natural and recreational potential along with the cultural and historical heritage of western Ukrainian cross-border regions, which contributed to the establishment of certain stages in an approach to tourism destinations and the identification of possible destination profiles;

- comparison of established tourism cluster activity in Ukraine and in neighboring countries, to establish a list of the main business structures that might be part of a cluster and become involved in the formation of tourism destinations;

- a survey to identify the interest of tourism business structures in western Ukrainian cross-border regions to the creation of tourism clusters;

- generalization, to determine the advantages of the western Ukrainian border regions in the creation of tourism destinations and the use of a cluster approach;

- modeling, in the development of the project model for the "Tourism Bukovyna" (Ukrainian: Туристична Буковина) cluster to become a basis for the formation of tourism destinations, and to provide diverse and innovative tourism development in western Ukrainian cross-border areas, etc.

\section{RESULTS}

The formation of tourism destinations in cross-border areas should be based on determining the uniqueness and attractiveness of natural and human tourism resources, opportunities for their use, analysis of general and special infrastructure, marketing, staffing and financial support, taking into account foreign experience and cross-border management, while making good managerial decisions.

Emphasizing the effective management of resources, Melnik states that

The basis of local community resource management should be a clear policy of local government on resource supply, resource use and resource efficiency, based on modern academic approaches, taking into account its resource capabilities. It should be based on certain basic principles, such as import substitution, balance; efficiency, synergy, economy, structure optimization, complementarity,; and the basis for an appropriate management mechanism (Melnik, 2018, p. 18).

and she offers a mechanism for managing the resources of an area with a complex matrix of interconnected elements.
Regarding the formation of tourism destinations in cross-border regions based on a cluster approach, and the need to create and operate clusters as a tool to increase the competitiveness of tourism destination products, there are features, goals and priorities. "From the viewpoint of the tourism sector, the nonhomogeneity of tourism products renders tourism clusters remarkably different from those in other economic industries. In other words, tourism clusters contain many complementary components not only from the private sector, but also from public institutions" (Yalçınkaya, Güzel, 2019, p. 28).

Defining a tourism destination as a geographical area that has particular borders and can attract and meet the needs of various groups of tourists, the creation of a tourism cluster will help to unite enterprises and organizations involved in tourism activities within the local community and focusing on end-user mediumsized enterprises.

The study of foreign experience, in particular, the study of the creation and functioning of clusters in Romania and Poland bordering on western regions, shows a large number of enterprises and organizations united in various forms and structures. Thus, up to 1 April 2020, 76 cluster initiatives were registered in the protocols of the Directorate for Industrial Policy and Competitiveness of Romanian Ministry of Economy, including 47 that are members of the cluster association, CLUSTERO, which is the representative body for the Romanian clusters that together united more than 2,000 enterprises, 189,000 employees and had a turnover of 43.6 billion lei (Situatia clusterelor din Romania, 2020)1.

Regarding the creation of tourism clusters, the study of their development in Poland confirms the integration of bodies working in the field of tourism in related sectors. They also play a significant role in activating local communities and transforming settlements and districts into tourism areas and increasing their competitiveness in the tourism market (Roman, 2013).

Analysis of tourism clusters in Poland: "Przemyśl - Tourism Cluster" (Przemyśl, 2016) and Małopolska Tourism Cluster (Kusa, Peszko, 2015); and in Romania: the Carpathian Tourism Cluster (Carpathian Tourism Cluster Romania, 2018) and the Medical Cluster "Health of Romania" (Clusterul Medical Sanatate Romania, 2019); confirmed the need to develop an approach where the main task is the step-by-step design of a tourism cluster and the separate stages of an approach to the formation of tourism destinations in the western Ukrainian border regions. Thus, in particular, the cluster approach to the formation of tourism destinations in cross-border areas has the following stages:

1. Diagnostic - which assesses its ecological status, natural recreational resources, cultural and historical 
heritage, existing tourism infrastructure, information, finance and staffing, the business environment, and the interest of government, business and community structures in creating a tourism destination based on a cluster approach.

2. Analytical - presented by analyzing the possibilities of combining tourism and other enterprises and organizations of cross-border regions into a cluster, studying the demand for tourism services of the destination and the formation of tourist flows from the cross-border areas of neighboring countries, organizing cross-border cooperation between tourism destinations and evaluating possible projects and participants.

3. Preparatory - which includes the development of the concept of a tourism destination based on a cluster approach and the necessary data system for the analysis of features and basic characteristics, conditions and factors of development for crossborder regions.

4. Organizational and structural - which provides for the creation of necessary coordination bodies, a system of measures and management mechanisms, taking into account the participation of crossborder areas in Euroregions and other cross-border bodies.

5. Strategic and prognostic - which involves the development of strategy and for forecasting the effectiveness of a tourism destination, the enterprises and organizations united in a cluster and in general the social, economic and environmental development of the cross-border area.

6. Control-corrective - which allows correlation of preliminary results with the goals set, to generalize positive experience, and to carry out regulation and adjustment.

It is important to note that the development of the concept of a tourism destination based on a cluster approach should be based entirely on the paradigm of sustainable development and its strategy which means that all enterprises and organizations in a tourism cluster must adapt to change by modifying management, marketing and other functional programs.

Comparison of the activities of established tourism clusters in Ukraine "Lvivske Opillya (Lviv region)" ( $\mathrm{Na}$ Lvivshchyni zyavyvsya..., 2020) and "Kamyanets" (center - Kamyanets-Podilsky) (Turystychnyy klaster, 2020) and of the above-mentioned tourism clusters in Poland and Romania, helped to establish a list of major business structures that can be part of a cluster and be involved in the formation of a tourism destination.

First, there are the powerful tour operators who produce, sell and export, travel services outside the region and the country.

Second, the network of enterprises and organizations that produce typical tourism services and supply them to the leading operators in the region and tourists as additional services.

Third, there are various organizations that provide key tourism enterprises with qualified personnel, financial resources, appropriate infrastructure, etc.

At the same time, it is established that the main reasons for combining these and other enterprises into a cluster are advantages for both enterprises and tourism destinations. Namely:

1. Expanding ties, mutual assistance and cooperation between many autonomous bodies, achieving synergies.

2. Increasing the productivity of fixed assets and increasing the ability to generate and maintain a competitive advantage.

3. The formation of an innovative environment that enhances the competitiveness of enterprises in the cluster by reducing costs and optimizing the value of tourism products at the destination.

4. Reducing the degree of risk, increasing the quality of service and improving the image of the destination area.

5. Increasing the investment attractiveness of the tourism destination, its management efficiency and marketing activities, by creating a new brand, combining capital, knowledge and skills.

Thus, the cluster approach to the formation of tourism destinations helps to unite cooperating and competing bodies within a specific organizational structure that has common goals and objectives that need to be fulfilled at a certain time and place.

Western Ukrainian cross-border regions, which include Volyn, Zakarpattia, Ivano-Frankivsk, Lviv and Chernivtsi, have borders with the EU, have a high potential for the development of many types of tourism. Thus, in particular, these are the regions richest in mineral waters, where there are more than 800 springs and wells with a total daily flow of $57500 \mathrm{~m}^{3}$. To date, the operational reserves of therapeutic mineral waters have been approved in only 13 places at $4600 \mathrm{~m}^{3} /$ day (Mazur, 2005). In the territories of these regions there is $19.6 \%$ of nature recreational potential (NRP) of the total NRP of Ukraine (Rudenko et al., 2019). In terms of western Ukrainian border areas, the NRP distributes as follows (Table 1).

As can be seen from Table 1, the largest NRP figure is found is in Zakarpattia and Lviv regions with 43 and $30 \%$, respectively, for sanatorium treatment resources, a significant factor influencing the formation of tourism destinations for recreation and health.

The situation is even better in western Ukrainian cross-border regions with cultural and historical heritage (Table 2). Within these regions are four out of seven Ukrainian UNESCO World Heritage Sites. Cultural and historical heritage of national importance in western Ukrainian cross-border regions, as noted by 
Table 1. Natural and recreational potential of western Ukrainian regions

\begin{tabular}{|l|c|c|c|}
\hline \multirow{2}{*}{$\begin{array}{l}\text { Western Ukraine } \\
\text { cross-border regions }\end{array}$} & \multirow{2}{|c|}{ Nature recreational potential } \\
\cline { 2 - 4 } & \multirow{2}{*}{ \% of total NRP in Ukraine } & \multicolumn{2}{|c|}{ including \% } \\
\cline { 2 - 4 } & & Recreational and tourism resources & Sanatorium treatment resources \\
\hline Volyn & 1.557 & 80 & 20 \\
\hline Zakarpattia & 7.036 & 57 & 43 \\
\hline Ivano-Frankivsk & 3.929 & 84 & 30 \\
\hline Lviv & 5.377 & 70 & 21 \\
\hline Chernivtsi & 1.744 & 79 & 26 \\
\hline Total & 19.6 & 74 & \\
\hline
\end{tabular}

Source: Rudenko et al. (2019, p. 198).

Table 2. Cultural and historical heritage of national importance in Western Ukrainian cross-border regions

\begin{tabular}{|l|c|c|c|c|c|c|}
\hline \multirow{2}{*}{$\begin{array}{c}\text { Western Ukrainian cross-border } \\
\text { regions }\end{array}$} & \multirow{2}{*}{\begin{tabular}{c} 
Total number of attractions \\
\cline { 3 - 7 }
\end{tabular}} & & \multicolumn{5}{|c|}{ Including monuments of national importance in: } \\
\cline { 3 - 7 } & history & monumental art & archeology & architecture & total \\
\hline Volyn & 1,961 & 7 & 1 & 16 & 200 & 224 \\
\hline Zakarpattia & 2,051 & 0 & 2 & 11 & 137 & 150 \\
\hline Ivano-Frankivsk & 3,947 & 2 & 1 & 10 & 149 & 162 \\
\hline Lviv & 8,441 & 7 & 1 & 14 & 794 & 816 \\
\hline Chernivtsi & 2,246 & 2 & 0 & 18 & 112 & 132 \\
\hline $\begin{array}{l}\text { Total in Western Ukrainian } \\
\text { cross-border regions }\end{array}$ & 18,646 & 18 & 5 & 69 & 1,392 & 1,484 \\
\hline Total in Ukraine & 131,293 & 142 & 44 & 418 & 3,541 & 4,145 \\
\hline
\end{tabular}

Source: Polyvach (2012, p. 97).

Polyvach was "The distribution of cultural heritage sites of national importance in terms of administrative areas is uneven. The regions with the highest number of monuments per $1000 \mathrm{~km}^{2}$ include Lviv, IvanoFrankivsk, Zakarpattia, Ternopil, Khmelnytsky, Chernivtsi, Volyn regions, Kyiv and Sevastopol" (Polyvach, 2012, p. 97).

Table 2 data show that only the Lviv region accounts for about $20 \%$ of monuments of national importance from all Ukrainian indicators, and in general the presence of such monuments in western Ukrainian cross-border regions is $35.8 \%$ of the total in sightseeing destinations at a regional level.

A survey conducted in October-December 2019 among managers of 140 travel companies and related companies in the western Ukrainian cross-border regions where tourism destinations can be established, gives grounds for claiming a great interest in creating tourism clusters. Thus, according to the results of the survey, out of 632 managers of travel and related companies, 427 would support the work of tourism clusters, business incubators and other regional bodies. Another 115 consider it less expedient to work in such associations, as it limits the activities of individual enterprises; the rest stated the need to clarify the benefits of working in a cluster.
Many academics understand the formation and development of tourism destinations exclusively by their impact on the economic condition of the area where the destination is established. In particular, this is the growth of gross regional product which, if it is a regional destination, means increasing incomes, creating new jobs, building infrastructure and other similar variables. At the same time, foreign experience and our research confirms that the effective functioning of tourism destinations in addition to economic indicators involves increased life expectancy, lower crime rates, higher education and health care, culture, sports and a number of others.

Therefore, tourism clusters should be formed not only from enterprises related to providing services to visitors, tourists, locals, but hotels, catering, transport, travel and tour companies, souvenir manufacturers and other bodies, along with individuals involved in the production and distribution of typical services located in the tourism destination. However, other enterprises and organizations, local and state authorities, educational, medical, cultural, sports, media, law enforcement, public association and others which are not related to tourism, should be fully involved. This approach is markedly different from existing concepts of tourism clusters, which, in our opinion, have limited capabilities. 
Based on the example of Chernivtsi region (Bukovyna) a draft concept of tourism development in the region and a draft model of the "Tourism Bukovyna" cluster will be the basis for the formation of a tourism destination that will provide a diverse and innovative nature of tourism development in the South-Western cross-border region of Ukraine.

Chernivtsi Regional State Administration has identified six "tourism magnets" (Chernivets'ka ODA vyznachyla, 2020), which include the historic center of Chernivtsi with the Residence of the Metropolitans of Bukovina and Dalmatia, a UNESCO World Heritage Site (Residence of Bukovinian and Dalmatian Metropolitans, 2011), the Regional Museum of Architecture and Life, the Khotyn Fortress, Pamir Radar Station, a cave monastery in the village of Halytsia (Ukrainian: Галиц, ) and a world center for Old Believers in the village of Bila Krynytsia (Ukrainian: Біла Криниця). These and other tourism sites of the Chernivtsi region are known throughout the world as monuments of culture, architecture, history, religious pilgrimage and contribute to great tourism demand not only in Ukraine but also from abroad. Each of them is located in a different district and together practically unite the whole territory of the region, justifying the formation of a regional tourism destination and the creation of the "Tourism Bukovyna" cluster.

The general purpose of the "Tourism Bukovyna" cluster is to provide an innovative type of destination formation which will contribute to the sustainable socio-economic development of cross-border region. The project model of "Tourism Bukovyna" cluster in Chernivtsi region is presented on Fig 1.

Offered in Fig. 1, the "Tourism Bukovyna" cluster model allows for a concentration within Chernivtsi region, as a regional tourism destination, a range of interconnected enterprises and organizations engaged in design, development, promotion, sale and provision of typical tourism services. The association of cross-border organizations, cross-border infrastructure enterprises, local and state authorities, other business and community structures can support the field of tourism.

The peculiarity of this approach to the formation of tourism destination is that it involves international cross-border missions in which the Chernivtsi region takes a significant part.

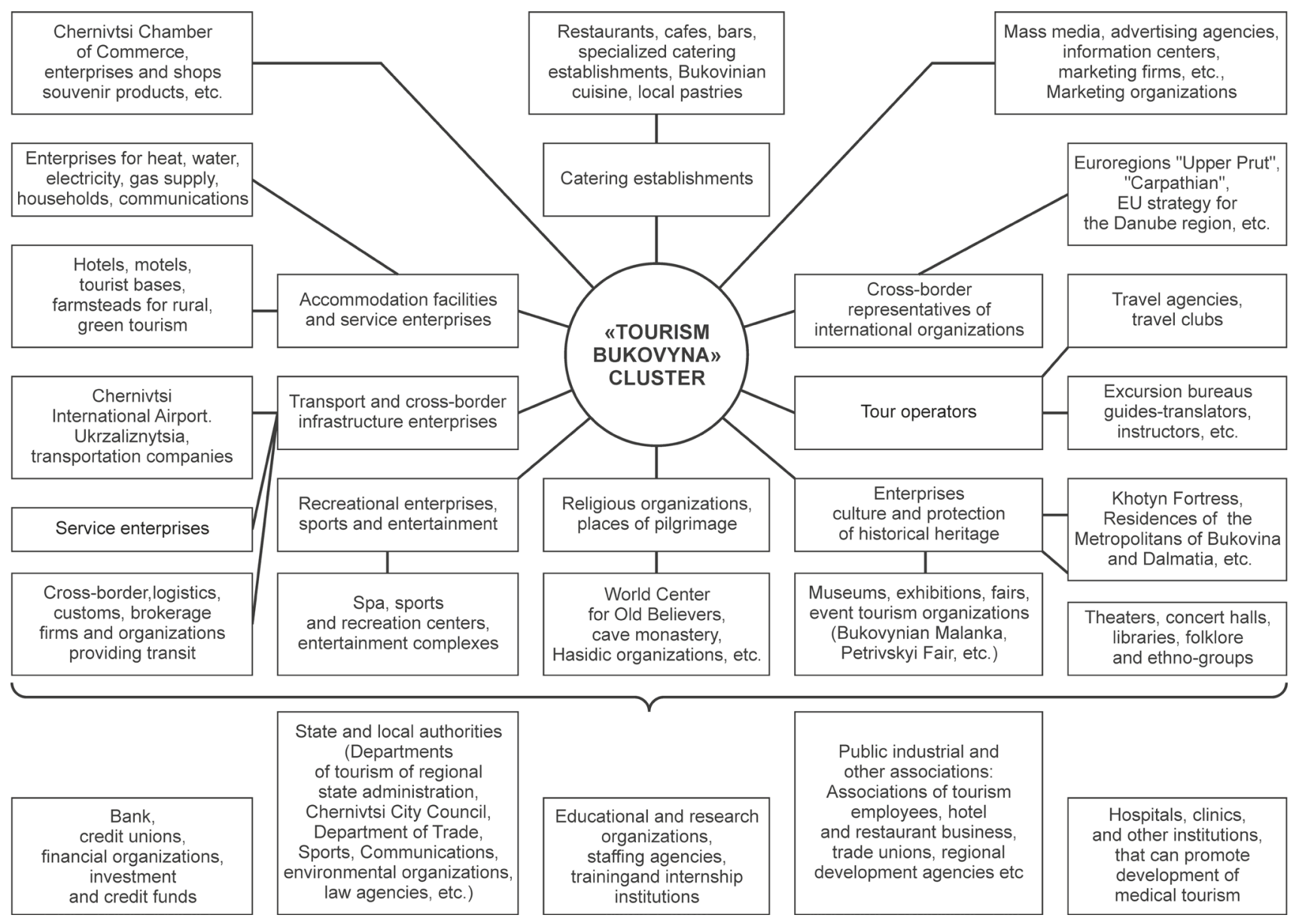

Figure 1. Project for the "Tourism Bukovyna" cluster model Source: developed by the authors 


\section{CONCLUSIONS AND SUGGESTIONS FOR FURTHER RESEARCH}

Based on the results of the research we can draw the following conclusions:

A cluster approach to the formation of tourism destinations in western Ukrainian cross-border regions, which have unique tourism resources, largely depends on those regional features which form both favorable conditions for tourism development and impose certain restrictions on the implementation of cluster initiatives. Therefore, in the period of planning and creating a tourism cluster and in the formation of destinations of particular importance, the decisions of regional authorities which are aware of strengths and weaknesses, can create attractive conditions for tourism and recreation, based on local tourism resources, available infrastructure, opportunities for tourist flows, finance and staffing, etc.

A cluster approach to tourism destinations and a proposed cluster model will promote the development of the following processes in regional economies:

- unification of business, government and public structures; institutions of science, education, culture, sports and others which will ensure the diverse and innovative nature of tourism development in western Ukrainian cross-border regions;

- an increase in the number of tourists, the volume of tourism services and the rate of regional economic growth;

- increasing the competitiveness of tourism products and the quality of tourism services;

- an increase in the volume of exports of tourism services to the cross-border regions of neighboring countries and a qualitative improvement of structure;

- increasing the investment attractiveness of western Ukrainian regions and the development of general border and special tourism infrastructure;

- the development of culture, sports, science and an improvement in the quality of education;

- creation of an innovation-oriented business environment.

A cluster approach to the formation of tourism destinations is a comprehensive approach for taking advantage of regional opportunities, and is an effective use of the resource potential of trends in the development of tourism.

\section{FURTHER RESEARCH}

Regarding prospects for further development, it would be important to determine the principles of tourism destination formation based on a cluster approach,
SWOT-analysis as a method of assessing internal and external factors, PEST-analysis to identify political, economic, social and technological aspects, and research into the influence of coronavirus on the processes of integration in tourism clusters.

\section{ENDNOTE}

${ }^{1} 10.16$ billion US dollars, as of June 13, 2020.

\section{REFERENCES}

Algieri, B., Aquino, A., Succurro, M. (2018). International competitive advantages in tourism: An eclectic view. Tourism Management Perspectives, 25, 41-52. https://doi.org/10.1016/j. tmp.2017.11.003

Bellini, N., Grillo, F., Lazzeri, G., Pasquinelli, C. (2017). Tourism and regional economic resilience from a policy perspective: Lessons from smart specialization strategies in Europe. Journal European Planning Studies, 25 (1), 140-153. https://doi.org/10.1 080/09654313.2016.1273323

Beltramo, R., Rostagno, A., Bonadonna, A. (2018). Land consolidation associations and the management of territories in harsh Italian environments: A review. Resources, 7. Retrieved from: https://www.mdpi.com/2079-9276/7/1/19 (15.07.2020). https:// doi.org/10.3390/resources7010019

Benner, M. (2017). From clusters to smart specialization: Tourism in institution-sensitive regional development policies. Economies, 5 (3), 26. https://doi.org/10.3390/economies5030026

Bobrovska, O.Y., Krushelnytska, T.A., Latinin, M.A., Lypovska, N.A., Dreshpak, V.M. (2017). Potentsial rozvytku terytoriy: metodolohichni zasady formuvannya i naroshchennya [Potential of territorial development: methodological principles of formation and increase]. Dnipro: DRIDU NADU [in Ukrainian].

Carpathian Tourism Cluster Romania (2020). Tourism-clusterromania.com. Retrieved from: http://tourism-cluster-romania. com/tourism-region/carpathian-mountains (23.07.2020).

Chernivets'ka ODA vyznachyla shist' «turystychnykh mahnitiv» Bukovyny [Chernivtsi Regional State Administration has identified six "tourism magnets" of Bukovina] (2020). Molbuk.ua. Retrieved from: https://molbuk.ua/chernovtsy_news/202752-chernivecka-oda-vyznachyla-6-turystychnykh-magnitiv-bukovyny. html (12.08.2020).

Clusterul Medical Sanatate Romania [Romania Health Medical Cluster] (2020). Sanatateromania.ro. Retrieved from: https://www.sanatateromania.ro/prezentare [in Romanian] (23.07.2020).

Gerasymenko, V. (ed.) (2016). Otsinka turystychno-rekreatsiynoho potentsialu rehionu [Assessment of tourism and recreational potential of the region]. Odessa: ONEU [in Ukrainian].

Korzh, N.V., Basyuk D.I. (2017). Upravlinnya turystychnymy destynatsiyamy [Management of tourism destinations]. Winnica: «PP «TD Edel'veys i K» [in Ukrainian].

Kravtsiv, V.S. (ed.). (2015). Rozvytok transkordonnoho spivrobitnytstva: naukovo-analitychna dopovid' [Development of crossborder cooperation: academic and analytical report]. Lviv: DU «Instytut rehional'nykh doslidzhen' imeni M.I. Dolishn'oho NAN Ukrayiny» [in Ukrainian].

Kusa, R., Peszko, A. (2020). Małopolski klaster turystyczny - perspektywy rozwoju w świetle badań własnych. Zarz.agh.edu.pl. 
Retrieved from: http://www.zarz.agh.edu.pl/rKusa/ZZ P19_06\%20MalopolskiKlasterTurystyczny.pdf (13.06.2020).

Mazaraki, A.A. (ed.) (2019). Ukraine and the world: The tourism system. Prague: Eatern European Center of the Fundamental Researchers (EECFR).

Mazur, F. (2005). Sotsial'no-ekonomichni umovy rozvytku rekreatsiynoyi industriyi (na prykladi Karpat.s'koho rehionu) [Socio-economic conditions for the development of the recreational industry (on the example of the Carpathian region)]. Kyiv: Tsentr Uchbovoyi Literatury [in Ukrainian].

Melnik, A.F. (2018). Upravlinnya resursamy terytoriyi v konteksti yevropeys'koyi ta natsional'noyi polityky rehional'noho rozvytku [Territory resource management in the context of European and national regional development policy]. Visnyk Ternopil's'koho natsional'noho ekonomichnoho universytetu - The Herald of Ternopil National Economic University, 3, 7-22 [in Ukrainian]. https://doi.org/10.35774/visnyk2018.03.007

Mikula, N., Matvyeyev, Y., Tymechko, I. (2014). Specific features of organization of new cross-border cooperation forms. In: R. Fedan, B. Petrecka, S. Dyrda-Maciałek (eds), Problemy wspótczesnej Europy - ujecie interdyscyplinarne (pp. 31-38). Jarosław: Wydawnictwo Państwowej Wyższej Szkoły TechnicznoEkonomicznej im. ks. Bronisława Markiewicza.

Na Lvivshchyni zyavyosya novyy turystychnyy klaster «Lvivske Opillya» [A new tourism cluster "Lvivske Opillya" has appeared in Lviv region] (2020). Decentralization.gov.ua. Retrieved from: https://decentralization.gov.ua/news/12162 (14.09.2020).

Naumanen, M. (2019). European panorama of clusters and industrial change: Emerging industries: Driving strength in 10 cross-sectoral industries. European Commission EC. Retrieved from: https:// cris.vtt.fi/en/publications/european-panorama-of-clusters-and-industrial-change-emerging-indu (20.01.2021).

Novelli, M., Schmitz, B., Spencer, T. (2006). Networks, clusters and innovation in tourism: A UK experience. Tourism Management, 27, 1141-1152. https://doi.org/10.1016/j.tourman.2005.11.011

Odinokova, T. (2019). Tourism cluster as a form of innovation activity. Economics. Ecology. Socium, 3 (2), 1-11. https://doi. org/10.31520/2616-7107/2019.3.2-1

Oteshova, A.K., Niyazbayeva, A.A., Prodanova, N.A., Patutina, N.A., Moshkin, A.S., Sabirova, R.K. (2020). Investment bases for the development of clusters at the regional level. Talent, Development \& Excellence, 12 (2), 768-775.
Polyvach, K.A. (2012). Kul'turna spadshchyna ta yiyi vplyv na rozvytok rehioniv Ukrayiny [Cultural heritage and its influence on the development of regions of Ukraine]. Kyiv: Institute of Geography, NAS of Ukraine [in Ukrainian].

Porter, M. (2005). Konkurentsyya [Competition]. Moscow: Izdatel'skiy dom «Vil'yams» [in Russian].

Porter, M. (2016). Konkurentnaya strategiya: Metodika analiza otrasley $i$ konkurentov [Competitive strategy: a methodology for analyzing industries and competitors]. Moscow: Alpina Publisher [in Russian].

Przemyśl - klaster turystyczny [Przemyśl - tourism cluster] (2020). Miasta.pl. Retrieved from: http://www.miasta.pl/aktualnosci/ przemysl-klaster-turystyczny (22.10.2020).

Residence of Bukovinian and Dalmatian Metropolitans (2020). Whc. unesco.org. Retrieved from: http://whc.unesco.org/en/list/1330 (4.09.2020).

Roman, M. (2013). Klastry jako forma współdziałania w działalności turystycznej. Zarządzanie i Finanse, 1 (3), 309-320.

Rudenko, V.P., Rudenko, S.V., Pidhirna, V.N., Tsependa, M.V., Yachnyuk, M.O., Vatseba, V.Y., Danilova, O.M., Hrytsku, V.S., Tsependa, M.M., Palamaryuk, M.Y., Chubrey, O.S., Yemchak, T.V., Rybchuk, Y.O., Kibych, I.V., Nakonechnyy, K.P., Burka, V.Y. (2019). Menedzhment turystychnoyi industriyi [Management of the tourism industry]. Chernivtsi: CHNU: Ruta [in Ukrainian].

Situatia clusterelor din Romania. Rezumat. Aprilie 2020 [Cluster situation in Romania. Summary. April 2020] (2020). Clustero. eu. Retrieved from: http://clustero.eu/wp-content/ uploads/2020/04/situatia-clusterelor-din-romania-aprilie-2020.pdf [in Romanian] (29.08.2020).

Stasiak, A. (2007). Klaster turystyczny - nowe wyzwanie dla ROT-ów i LOT-ów? Rocznik Naukowy Wyższej Szkoły Turystyki i Rekreacji im. M. Ortowicza w Warszawie, 6, 183-196.

Turystychnyy klaster "Kamyanets'» [Kamyanets tourism cluster] (2020). Clarity-project.info. Retrieved from: https://clarity-project.info/edr/26514268 (13.09.2020).

Varnalius, Z.S. (ed.). (2005). Rehiony Ukrayiny: Problemy ta priorytety sotsial'no-ekonomichnoho rozvytku [Regions of Ukraine: problems and priorities of socio-economic development]. Kyyiv: Znannya Ukrainy [in Ukrainian].

Yalçınkaya, T., Güzel, T. (2019). A general overview of tourism clusters. Journal of Tourism Theory and Research, 5 (1), 28-39. https://doi.org/10.24288/jttr.465912 